\title{
Malus sieversii: A Diverse Central Asian Apple Species in the USDA-ARS National Plant Germplasm System
}

\author{
Gayle M. Volk ${ }^{2}$, Adam D. Henk, and Christopher M. Richards \\ USDA-ARS National Center for Genetic Resources Preservation, 1111 South \\ Mason Street, Fort Collins, CO 80521
}

Philip L. Forsline

USDA-ARS Plant Genetic Resources Unit, Geneva, NY 14456

\section{Thomas Chao ${ }^{1}$}

USDA-ARS National Center for Genetic Resources Preservation, 1111 South Mason Street, Fort Collins, CO 80521

Additional index words. genepool, genetic diversity, Malus pumila, subspecies, taxonomy

Abstract. There are several Central Asian Malus species and varieties in the USDA-ARS National Plant Germplasm System (NPGS) apple collection. Malus sieversii is the most comprehensively collected species native to Central Asia. Other taxa such as M. sieversii var. kirghisorum, M. sieversii var. turkmenorum, M. pumila, and M. pumila var. niedzwetzkyana have primarily been donated to the collection by other institutions and arboreta. We sought to determine if genetic and/or phenotypic differences among the individuals that make up the gene pools of these taxa in the NPGS exhibit unique characteristics. Genetic data, based on microsatellite analyses, suggested that the diversity within each taxa is significantly greater than that among taxa. Trait data also revealed very few differences among taxa, the primary characteristic being the dark red fruit coloration and tinted flesh color of the accessions assigned to M. pumila var. niedzwetzkyana resulting from a known single-gene mutation in anthocyanin production. We found that $M$. sieversii is a highly diverse species with a range in genetic and phenotypic trait variation that includes the characteristics of the other Central Asian taxa of interest. We conclude that the gene pools that comprise the accessions within the NPGS Central Asian Malus collection are highly overlapping with respect to both phenotypic traits and genotypic characters.

The mountains of Central Asia have forest species that include Malus sieversii (Ledeb.) M. Roem., a highly diverse apple crop wild relative. The Russian scientist Vavilov explored the forests of Central Asia in the 1920s and made note of the wide range of $M$. sieversii phenotypes, suggesting that this region, including Kazakhstan, Kyrgyzstan, Tajikistan, and western China, is a center of origin for the domesticated apple (Luby et al., 2001; Wan et al., 2011; Yan et al., 2008). Malus sieversii grows in a wide range of habitats, including areas with hot summers and short winters as well as those with long, severe winters in the Tien Shan Mountains (Dzhangaliev, 2003). Wild populations are found in montane, scrub, humid as well as dry continental forests and in diverse stream habitats in xeric areas (Forsline et al., 2003). Malus sieversii trees are phenotypically diverse, offering variation in the time of flowering, quantity and quality of fruit, ripening period, fruit biochemical composition, tree architecture, winter and

Received for publication 18 June 2013. Accepted for publication 17 Sept. 2013

${ }^{1}$ Retired.

${ }^{2}$ To whom reprint requests should be addressed; e-mail gvolk@lamar.colostate.edu. drought tolerance, and disease resistance (Dzhangaliev, 2003; Yan et al., 2008; Zhou, 1999).

The U.S. Department of Agriculture (USDA) sponsored four plant exploration trips in Central Asia to collect wild apples between 1989 and 1996. Participants on those trips sought clones with unusual phenotypes and collected seeds from trees growing in diverse habitats, primarily in Kazakhstan. Over 1000 seedlings from the wild-collected seeds have been grown in Geneva, NY, in the USDA-ARS NPGS apple collection. Most of the seedlots were assigned to the $M$. sieversii species, although some have been labeled as Malus sieversii var. kirghisorum (Al. Fed. \& Fed.) Ponomar. The repository also has a number of accessions that have been classified as Central Asian taxa, namely Malus sieversii var. turkmenorum (Juz. \& Popov) Ponomar. and Malus pumila Mill. Malus pumila var. niedzwetzkyana Dieck. was formerly listed as a variety but in 2010 was reclassified as $M$. pumila. Many of these accessions were donated to the repository from other gene banks or arboreta. In addition to these species/varieties, the literature describes a number of variations in nomenclature for Central Asian Malus species, subspecies, and varieties including: M. niedzwetzkyana,
M. dasyphylla, and M. kirghisorum. In the Genetic Resources Information Network (GRIN; USDA, ARS, National Genetic Resources Program, 2013), these are synonymous with $M$. pumila var. niedzwetzkyana, M. pumila, and M. sieversii var. kirghisorum, respectively. Dzhangaliev (2003) summarized the Malus species native to Kazakhstan. $M$. sieversii and $M$. niedzwetazkyana are most similar to cultivated apple with $M$. niedzwetzkyana as a botanical variety of M. dasyphylla. Furthermore, M. kirghisorum is described as distinct from $M$. sieversii because it grows adjacent to relic Juglans regia forests as part of a mesophilous Turgai forest flora with a limited range in Dzhungareskei and Zailijskei Alatau (Dzhangaliev, 2003).

Based on molecular and phenotypic evidence, $M$. sieversii is likely a progenitor species of the domesticated apple, Malus $\times$ domestica (Harris et al., 2002; Velasco et al., 2010; Zhou and $\mathrm{Li}, 2000)$. In fact, $M$. sieversii and $M$. $\times$ domestica have sometimes been coclassified as M. pumila (Harris et al., 2002; Juniper and Mabberley, 2006; Phipps et al., $1990,1991)$. Although there are data suggesting similarities between these species, genetic evidence suggests that they can be genetically distinguished based on microsatellite markers (Gross et al., 2012). In fact, putative hybrids between $M$. sieversii and $M$. $\times$ domestica can also be identified, thus further supporting the differentiation of these species (Gross et al., 2012). Other species such as $M$. orientalis, M. sylvestris, and M. prunifolia likely played a role in Malus domestication (Coart et al., 2006; Cornille et al., 2012; Forte et al., 2002; Gross et al., 2012; Luby, 2003; Robinson et al., 2001; Velasco et al., 2010). Single nucleotide polymorphism transferability was $\approx 26 \%$ from M. $\times$ domestica to either $M$. sieversii or $M$. sylvestris, supporting the evidence that there are significant genomic differences among $M$. ×domestica and its likely progenitor species (Micheletti et al., 2011).

Previously, we assessed the diversity of the $M$. sieversii collection in the USDA-ARS NPGS using microsatellite markers. Collection sites were significantly differentiated and had unique alleles; however, differentiation within individual families was more than three times the level of that among sites. Differentiation was congruent with geographical location with southwestern collection sites being more admixed and more diverse than the northern sites (Richards et al., 2009b). These data supported results published previously that used isozymes to determine within- and among-population differences in M. sieversii collections (Lamboy et al., 1996).

Core collections were also proposed using available microsatellite and quantitative trait data for the $M$. sieversii trees from Kazakhstan in the NPGS. Three sets of 35 trees, representative of Site 6 , Site 9, and "other" collection sites, were identified as core collections that capture greater than $95 \%$ of the measured allelic and phenotypic diversity 
(Forsline et al., 2003; Richards et al., 2009a; Volk et al., 2005).

Malus sieversii accessions in the NPGS have been evaluated for a number of fruit, biotic, and abiotic stress resistance traits both on-site in Geneva, NY, and by collaborators. Physiological and phenological traits such as high chilling requirement, early fruit maturity, short juvenility, dwarf growth habit, late flowering, stooling ability, and vigor were of particular interest to breeding programs (Bassett et al., 2011; Fazio et al., 2009; Forsline and Aldwinckle, 2004; Forsline et al., 2003; Luby et al., 2001, 2002). In addition, sources of disease and insect resistance have been identified for apple scab (Venturia inaequalis), fireblight (Erwinia amylovora), cedar apple rust (Gymnosporangium juniper-virginianae), Rosellinia necatrix, Helicobasidium mompa, woolly apple aphid (Eriosoma lanigerum), apple leaf curling midge (Dasineura mali), soilborne apple replant pathogens, and apple maggot (Rhagoletis pomonella) (Fazio et al., 2009; Forsline and Aldwinckle, 2004; Forsline et al., 2003; Luby et al., 2001, 2002). Characterized fruit traits include aroma, flavor, size, color, weight, texture, soluble solids, $\mathrm{pH}$, and volatile components (Bai et al., 2012; Fazio et al., 2009; Forsline and Aldwinckle, 2004; Forsline et al., 2003; Luby et al., 2001, 2002). Some traits even differed by collection site such as the later harvest time and an increased level of fireblight resistance in Site 6 and larger, red fruit more common in Site 9 (Forsline and Aldwinckle, 2004).

The large $M$. sieversii collection in the NPGS provided us with an opportunity to assess the relationship among accessions collected and labeled as $M$. sieversii to those that have been classified as related species/ varieties: $M$. sieversii var. kirghisorum, M. sieversii var. turkmenorum, M. pumila, and M. pumila var. niedzwetzkyana. We use genotypic and phenotypic data to determine if the gene pools in the NPGS that comprise these taxa can be distinguished from one another.

\section{Materials and Methods}

Malus sieversii and several accessions of $M$. sieversii var. kirghisorum seeds were collected from forests in the Tien Shan Mountains in Kazakhstan and Kyrgyzstan in the 1990s (Forsline et al., 2003; Luby et al., 2001). Seeds were germinated and planted as own-root seedlings within an orchard setting. Clones representing individuals of the other Central Asian taxa were provided to the NPGS by donors and are maintained as grafted trees within the collection (Table 1). A total of $99 M$. sieversii, nine $M$. sieversii var. kirghisorum, three $M$. sieversii var. turkmenorum, eight M. pumila, and three M. pumila var. niedzwetzkyana trees were available for inclusion in this research.

Genetic comparisons among accessions assigned to the five Malus species/varieties were performed using microsatellite markers. DNA extraction, polymerase chain reaction amplifications, and allele identifications have been described previously (Volk et al., 2005). Two sets of data were available. A total of 18 simple sequence repeat (SSR) loci (GD12, GD15, GD96, GD142, GD147, GD162, CH01h01, CH01f02, CH01d08, CH01f07a, CH05e03, CH02d12, CH02b10, COL, NH009b, CH01d09, NZ28f4, NH015a; Guilford et al., 1997; Hokanson et al., 1998; Liebhard et al., 2002; Yamamoto et al., 2002) were available to compare 111 accessions

Table 1. National Plant Germplasm System accessions of Malus pumila, M. pumila var. niedzwetzkyana, M. sieversii var. kirghisorum, and M. sieversii var. turkmenorum for which phenotypic and/or genotypic data were available.

\begin{tabular}{|c|c|c|c|c|c|c|}
\hline Taxon & Accession & Local number & $\begin{array}{c}\text { SSR loci } \\
\text { available } \\
\text { (no.) }\end{array}$ & $\begin{array}{c}\text { Admixture } \\
\text { (Gross et al., 2012) }\end{array}$ & $\begin{array}{l}\text { Original collection } \\
\text { country }\end{array}$ & Donor \\
\hline Malus pumila & PI 323617 & GMAL 3163 & 5 & & Afghanistan & Arnold Arboretum \\
\hline Malus pumila & PI 588827 & GMAL 140 & 5 & & & $\begin{array}{l}\text { Finland (through Agriculture } \\
\text { Canada) }\end{array}$ \\
\hline Malus pumila & PI 588916 & GMAL 244 & 5 & & & Morton Arboretum \\
\hline Malus pumila & PI 589166 & GMAL 1016 & 5 & & & Cornell University \\
\hline Malus pumila & PI 590096 & GMAL 3370 & 5 & & & Arnold Arboretum \\
\hline Malus pumila & PI 590097 & GMAL 3378 & 5 & & & Arnold Arboretum \\
\hline Malus pumila & PI 590098 & GMAL 3379 & 5 & & & Arnold Arboretum \\
\hline Malus pumila & PI 594106 & GMAL 3223 & 5 & & & Beijing Botanical Garden \\
\hline $\begin{array}{l}\text { Malus pumila } \\
\quad \text { var. niedzwetzkyana }\end{array}$ & PI 589225 & GMAL 1223 & 5 & & $\begin{array}{l}\text { Turkestan/southwest } \\
\text { Siberia }\end{array}$ & $\begin{array}{l}\text { Arnold Arboretum } \\
\text { (through Cornell University) }\end{array}$ \\
\hline $\begin{array}{l}\text { Malus pumila } \\
\quad \text { var. niedzwetzkyana }\end{array}$ & PI 589287 & GMAL 1389 & 5 & & & District of Columbia \\
\hline $\begin{array}{l}\text { Malus pumila } \\
\quad \text { var. niedzwetzkyana }\end{array}$ & PI 589857 & GMAL 2613 & 5 & & & University of Maine \\
\hline $\begin{array}{l}\text { Malus sieversii } \\
\quad \text { var. kirghisorum }\end{array}$ & PI 589373 & GMAL 1740 & 18 & & & Morton Arboretum \\
\hline $\begin{array}{l}\text { Malus sieversii } \\
\text { var. kirghisorum }\end{array}$ & PI 589380 & GMAL 1750 & 18 & & & Morton Arboretum \\
\hline $\begin{array}{l}\text { Malus sieversii } \\
\text { var. kirghisorum }\end{array}$ & PI 590043 & GMAL 3158 & 18 & & & Arnold Arboretum \\
\hline $\begin{array}{l}\text { Malus sieversii } \\
\text { var. kirghisorum }\end{array}$ & PI 590094 & GMAL 3367 & 18 & $\mathrm{x}$ & & Arnold Arboretum \\
\hline $\begin{array}{l}\text { Malus sieversii } \\
\text { var. kirghisorum }\end{array}$ & PI 613854 & GMAL 2288.a1 & 18 & $\mathrm{x}$ & & $\begin{array}{l}\text { Vavilov Research Institute } \\
\text { of Plant Industry }\end{array}$ \\
\hline $\begin{array}{l}\text { Malus sieversii } \\
\text { var. kirghisorum }\end{array}$ & PI 613855 & GMAL 2288.b1 & & $\mathrm{x}$ & & $\begin{array}{l}\text { Vavilov Research Institute } \\
\text { of Plant Industry }\end{array}$ \\
\hline $\begin{array}{l}\text { Malus sieversii } \\
\text { var. kirghisorum }\end{array}$ & PI 613968 & GMAL 4445 & 18 & $\mathrm{x}$ & Kazakhstan & USDA collection trip \\
\hline $\begin{array}{l}\text { Malus sieversii } \\
\quad \text { var. kirghisorum }\end{array}$ & PI 633798 & GMAL 3574 & 18 & & Kyrgyzstan & USDA collection trip \\
\hline $\begin{array}{l}\text { Malus sieversii } \\
\text { var. kirghisorum }\end{array}$ & PI 657001 & GMAL 3583 & 18 & & Kyrgyzstan & USDA collection trip \\
\hline $\begin{array}{l}\text { Malus sieversii } \\
\quad \text { var. turkmenorum }\end{array}$ & PI 594104 & GMAL 2251 & 5 & & & $\begin{array}{l}\text { Vavilov Research Institute } \\
\text { of Plant Industry }\end{array}$ \\
\hline $\begin{array}{l}\text { Malus sieversii } \\
\quad \text { var. turkmenorum }\end{array}$ & PI 613851 & GMAL 2251 & 5 & & & $\begin{array}{l}\text { Vavilov Research Institute } \\
\text { of Plant Industry }\end{array}$ \\
\hline $\begin{array}{l}\text { Malus sieversii } \\
\text { var. turkmenorum }\end{array}$ & PI 613852 & GMAL 2251 & 5 & & & $\begin{array}{l}\text { Vavilov Research Institute } \\
\text { of Plant Industry }\end{array}$ \\
\hline
\end{tabular}

$\mathrm{SSR}=$ simple sequence repeat; USDA = U.S. Department of Agriculture. 
assigned to $M$. sieversii with nine accessions assigned to $M$. sieversii var. kirghisorum. Another data set with five SSR loci (GS12, GD15, GD142, GD147, GD162) was used to compare $61 \mathrm{M}$. sieversii accessions with three $M$. sieversii var. turkmenorum, eight $M$. pumila, and three M. pumila var. niedzwetzkyana accessions. Analyses of multivariance (AMOVA) determined the among- and withinpopulation variation for each data set. DARwin software was used to graphically display the interindividual differences among accessions within each data set. Genetic distances were calculated using a simple matching coefficient.

Bayesian structure analyses were performed to determine if individuals could be assigned to groups that corresponded to species, subspecies, or varieties without a priori taxa definitions (Pritchard et al., 2000). Individuals in the five SSR and 18 SSR data sets were analyzed independently.

Phenotypic data were primarily collected for a single season for each accession between 1996 and 2003, when the trees were mature. Phenotypic data were collected according to descriptors that are described in the GRIN database (USDA, ARS, National Genetic Resources Program, 2013). Trait data for each descriptor were compared across the five Malus species/varieties. Categorical data were analyzed using $\chi^{2}$ analyses and likelihood ratio tests to determine significance. Quantitative data were compared using analyses of variance and Tukey-Kramer honestly significant difference means comparisons.

\section{Results}

Malus sieversii is a broadly defined species native to Kazakhstan, Kyrgyzstan, Tajikistan, Uzbekistan, and China. Many accessions of this species are accessible through the NPGS as a result of collection trips to Central Asia in the 1990s. In contrast, fewer individuals represent $M$. sieversii var. kirghisorum, $M$. sieversii var. turkmenorum, M. pumila, and M. pumila var. niedzwetzkyana in the NPGS (Table 1). Interindividual distances, genetic assignments, and genetic differentiation analyses were used to identify differences among the designated gene pools.

All three of the M. pumila var. niedzwetzkyana accessions in the data set had identical scores for the five SSRs tested. It is likely that these are clones of the same individual. AMOVA results for the 18 SSR data sets revealed no statistical differences between the microsatellite scores for $M$. sieversii and M. sieversii var. kirghisorum. Using AMOVA, we found $2 \%$ of the variation explained differences among varieties (Table 2). There were also no differences among $M$. sieversii accessions and $M$. sieversii var. turkmenorum, M. pumila, and M. pumila var. niedzwetzkyana accessions in the NPGS. Like in the 18 SSR data sets, most of the variation $(91 \%)$ is attributed to within-taxa and a small portion $(9 \%)$ is among the taxa (Table 3 ).

A dissimilarity index as determined by using DARwin software was used to construct an unrooted neighbor joining tree with

Table 2. Comparison of Malus sieversii and Malus sieversii var. kirghisorum apple accessions in the National Plant Germplasm System using data for 18 microsatellites.

\begin{tabular}{lrccc}
\hline Source of variation & df & $\begin{array}{c}\text { Sum } \\
\text { of squares }\end{array}$ & Variance components & $\begin{array}{r}\text { Percentage } \\
\text { of variation }\end{array}$ \\
\hline Among species/varieties & 1 & 11.3 & 0.14 & 1.91 \\
Within species/varieties & 232 & 1662 & 7.16 & 98.09 \\
\hline
\end{tabular}

Table 3. Comparison of Malus sieversii, M. sieversii var. turkmenorum, Malus pumila, and M. pumila var. niedzwetzkyana accessions within the National Plant Germplasm System using data for five microsatellites.

\begin{tabular}{lcccc}
\hline Source of variation & df & $\begin{array}{c}\text { Sum } \\
\text { of squares }\end{array}$ & Variance components & $\begin{array}{r}\text { Percentage } \\
\text { of variation }\end{array}$ \\
\hline $\begin{array}{l}\text { Among } \\
\text { species/varieties }\end{array}$ & 3 & 14 & 0.18 & 8.91 \\
$\begin{array}{l}\text { Within } \\
\text { species/varieties }\end{array}$ & 140 & 254.7 & 1.82 & 91.09 \\
\hline
\end{tabular}

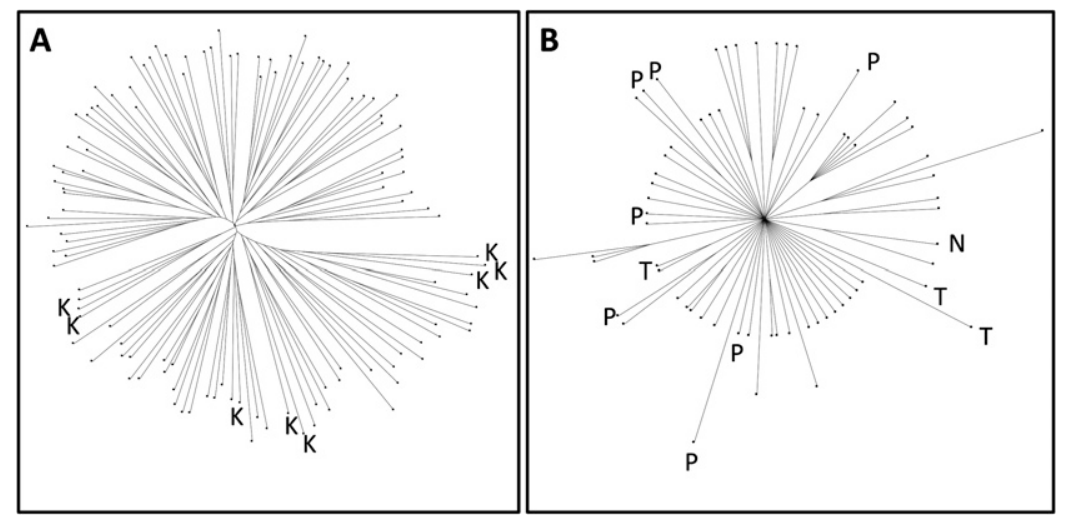

Fig. 1. Graphical representation from DARwin analyses. Each sample is represented as a terminal node in the neighbor-joining tree for (A) Malus sieversii (unlabeled) and M. sieversii var. kirghisorum (K) in the 18 simple sequence repeat (SSR) data set and (B) M. sieversii (unlabeled) and M. pumila (P), M. pumila var. niedzwetzkyana $(\mathrm{N})$, and M. sieversii var. turkmenorum $(\mathrm{T})$ for the five SSR data sets.

the 18 SSR and five SSR sets of data (Fig. 1). Individuals from each species/variety were identified. For both data sets, the non- $M$. sieversii individuals were dispersed throughout the trees rather than occurring together. This suggests that the genetic diversity encompassed by $M$. sieversii is broader than that of the other species and varieties.

Results from structure analysis showed no significant discontinuity. Using either the 18 locus data set to separate $M$. sieversii var. kirghisorum variety for $M$. sieversii or using the five locus data to partition the M. pumila accessions, results indicated no supportable partition among the named taxa. Admixture models with or without taxon identity as priors resulted in the same lack of separation. Admixture was evenly distributed among each of the named taxa indicating that linkage disequilibrium has not built up among these accessions (data not shown).

Image data are available for many of the accessions included in these analyses (Supplementary Fig. 1). Overall, the images of M. sieversii, $M$. sieversii var. kirghisorum, $M$. sieversii var. turkmenorum, and $M$. pumila are similar and overlapping in the range of variation observed for each taxon. In contrast. M. pumila var. niedzwetzkyana is distinct. These apples are dark red to purple and exhibit some degree of red coloration in the flesh.

Many of the phenotypic data for the NPGS apple collection are categorical; however, data for fruit length, fruit width, overcolor, and soluble solids were collected quantitatively. Malus sieversii had the smallest average fruit length $(39.7 \pm 0.6 \mathrm{~mm})$ and width $(44.2 \pm 0.7 \mathrm{~mm})$ among the species and varieties compared (Table 4). Statistically, the fruit length was the same for all the species/varieties except $M$. pumila var. niedzwetzkyana, which had larger length and width. In addition, the $M$. sieversii var. kirghisorum fruit were wider than the $M$. sieversii fruit. The overcolor percentage of the $M$. sieversii fruit was lower than that of the M. pumila and the solid-colored M. pumila var. niedzwetzkyana. $M$. sieversii had the same soluble solids as the accessions representing other species/varieties (Table 4).

Chi square analyses among NPGS accessions assigned to $M$. sieversii, $M$. sieversii var. kirghisorum, M. sieversii var. turkmenorum, M. pumila, and M. pumila var. niedzwetzkyana revealed no significant differences for the following traits: calyx persistence, calyx basin, fruit flesh flavor, fruit flesh firmness, fruit juiciness, fruit firmness, fruit flesh oxidation, fruit weight, fruit ground 
Table 4. Quantitative phenotypic trait values among Central Asian Malus species/varieties.

\begin{tabular}{lcccc}
\hline & $\begin{array}{c}\text { Fruit length } \\
(\mathrm{mm})\end{array}$ & $\begin{array}{c}\text { Fruit width } \\
(\mathrm{mm})\end{array}$ & $\begin{array}{c}\text { Overcolor } \\
(\%)\end{array}$ & $\begin{array}{c}\text { Soluble } \\
\text { solids }(\%)\end{array}$ \\
\hline $\begin{array}{l}\text { Malus sieversii } \\
\begin{array}{c}\text { Malus sieversii } \\
\text { var. kirghisorum }\end{array}\end{array}$ & $39.7 \pm 0.6 \mathrm{~b}$ & $44.2 \pm 0.7 \mathrm{~b}$ & $28 \pm 3 \mathrm{c}$ & $11.9 \pm 0.1 \mathrm{ab}$ \\
$\begin{array}{l}\text { Malus sieversii } \\
\text { var. turkmenorum }\end{array}$ & $46.0 \pm 5.3 \mathrm{~b}$ & $53.3 \pm 4.9 \mathrm{a}$ & $51 \pm 10 \mathrm{bc}$ & $13.1 \pm 0.5 \mathrm{a}$ \\
$\begin{array}{l}\text { Malus pumila } \\
\text { Malus pumila } \\
\text { var. niedzwetzkyana }\end{array}$ & $45.8 \pm 11.8 \mathrm{ab}$ & $54.0 \pm 12.0 \mathrm{ab}$ & $70 \pm 5 \mathrm{abc}$ & $11.9 \pm 1.2 \mathrm{ab}$ \\
\hline
\end{tabular}

Means, standard errors, and significant differences between Malus species/varieties were determined using Tukey means separation tests $(P<0.05)$.

color, harvest season, overcolor pattern, top fruit shape, stem cavity, fruit russet location, and fruit bloom.

Some traits differed among the Central Asian species/varieties. Several fruit color traits, including fruit flesh color and fruit overcolor, were significantly different for M. pumila var. niedzwetzkyana than the four other species/varieties. The fruit flesh color of M. pumila var. niedzwetzkyana was cream and red, red, or rose, whereas most of the other fruit flesh colors were shades of white and cream. Likewise, the fruit overcolor of M. pumila var. niedzwetzkyana accessions was dark red or purple-red and the other fruits were mostly green, yellow, orange, brown, or red. In addition, the fruit of M. pumila var. niedzwetzkyana were classified as conical, whereas those of the other species/varieties were mostly globose or flat.

With respect to fruit weight, a higher proportion of $M$. sieversii had small fruit (less than $50 \mathrm{~g}$ ) than the accessions of the other four taxa. M. sieversii also had more variable fruit shape and size uniformity than the other types. This might be indicative of the large sample size available for $M$. sieversii phenotypic measurements and that this species is generally diverse for many traits.

\section{Discussion}

The NPGS collection of $M$. sieversii is a valuable resource for research and breeding programs. The accessions within this collection display wide range of phenotypic and genetic diversity and have the potential to provide novel alleles for key breeding traits. The collection has relatively few accessions that represent other related taxa, including M. pumila, M. pumila var. niedzwetzkyana, M. sieversii var. kirghisorum, and M. sieversii var. turkmenorum. The purpose of this research was to determine if the gene pools that comprised these other taxa overlapped significantly with those designated as $M$. sieversii.

Phenotypic data exhibit a high level of similarity among Central Asian Malus taxa in the NPGS. The one exception is the three identical clones that were formerly classified as M. pumila var. niedzwetzkyana. These are unique with dark red skin and tinted flesh. M. pumila var. niedzwetzkyana has been examined previously (Chagné et al., 2013; Van Nocker et al., 2012). Nearly all of the red-fleshed apple cultivars in collections worldwide all could all be traced back to a mutation in a transcriptional regulator of anthocyanin biosynthesis. This specific mutation confers the red-fleshed trait and the presence alone of this allele.

Malus pumila is a taxon that includes M. $\times$ domestica and M. sieversii (Harris et al., 2002; Juniper and Mabberley, 2006). Although these species do exhibit similarities, genetic data suggest that they are distinct (Gross et al., 2012). Our analyses do not differentiate the accessions of M. pumila in the NPGS from those of $M$. sieversii.

The taxonomy of the Central Asian wild apple species is complex. Many species have been identified in the literature and then subsequently renamed (Korban and Skirvin, 1984). In some cases, accessions that are donated to the NPGS from other institutions have retained their original species classifications. As a result, the few numbers of accessions of these taxa can lead curators to believe that they have some species that may be underrepresented in their collections. Careful assessments of the validity of the assignments to taxa may clear up these misconceptions. Accessions that may be viewed as particularly novel based on their taxonomic identities may in fact be quite similar to those already represented in the collection.

The results from this research assert that the $M$. sieversii collection in the NPGS displays a range of genotypic and phenotypic diversity that encompasses that of related taxa M. pumila, M. pumila var. niedzwetzkyana, M. sieversii var. kirghisorum, and M. sieversii var. turkmenorum. The gene pools represented by the individuals within these taxa are highly overlapping.

\section{Literature Cited}

Bai, Y., L. Dougherty, M. Li, G. Fazio, L. Cheng, and K. Xu. 2012. A natural mutation-led truncation in one of the two aluminum-activated malate transporter-like genes at the $M a$ locus is associated with low fruit acidity in apple. Mol. Genet. Genomics 287:663-678.

Bassett, C.L., D.M. Glenn, P.L. Forsline, M.E. Wisniewski, and R.E. Farrell. 2011. Characterizing water use efficiency and water deficit responses in apple (Malus $\times$ domestica Borkh. and Malus sieversii Ledeb.) M. Roem. HortScience 46:1079-1084.

Chagné, D., K. Lin-Wang, R.V. Espley, R.K. Volz, N.M. How, S. Rouse, C. Brendolise, C.M. Carlisle, S. Kumar, N. De Silva, D. Micheletti, T. McGhie, R.N. Crowhurst, R.D. Storey, R. Velasco, R.P. Hellens, S.E. Gardiner, and A.C. Allan. 2013. An ancient duplication of apple
MYB transcription factors is responsible for novel red fruit-flesh phenotypes. Plant Physiol. 161:225-239.

Coart, E., S. Van Glabeke, M. De Loose, A.S Larsen, and I. Roldan-Ruiz. 2006. Chloroplast diversity in the genus Malus: New insights into the relationship between the European wild apple [Malus sylvestris (L.) Mill.] and the domesticated apple (Malus domestica Borkh.). Mol. Ecol. 15:2171-2182.

Cornille, A., P. Gladieux, M.J.M. Smulders, I. Roldan-Ruiz, F. Laurens, B. Le Cam, A. Nersesyan, J. Clavel, M. Olonova, L. Feugey, I. Gabrielyan, X.-G. Zhang, M.I. Tenaillon, and T. Giraud. 2012. New insight into the history of domesticated apple: Secondary contribution of the European wild apple to the genome of cultivated varieties. PLoS Genet. 8:e1002703.

Dzhangaliev, A.D. 2003. The wild apple tree of Kazakhstan. Hort. Rev. 29:65-304.

Fazio, G., H.S. Aldwinckle, G.M. Volk, C.M. Richards, W. Janisiewicz, and P.L. Forsline. 2009. Progress in evaluating Malus sieversii for disease resistance and horticultural traits. Acta Hort. 814:59-66.

Forsline, P.L. and H.S. Aldwinckle. 2004. Evaluation of Malus sieversii seedling populations for disease resistance and horticultural traits. Acta Hort. 663:529-534.

Forsline, P.L., H.S. Aldwinckle, E.E. Dickson, J.J. Luby, and S.C. Hokanson. 2003. Collection, maintenance, characterization, and utilization of wild apples of Central Asia. Hort. Rev. 29:1-62.

Forte, A.V., A.N. Ignatov, V.V. Ponomarenko, D.B. Dorokhov, and N.I. Savelyev. 2002. Phylogeny of the Malus (apple tree) species, inferred from the morphological traits and molecular DNA analysis. Russ. J. Genet. 38:13571369.

Gross, B.L., A.D. Henk, P.L. Forsline, C.M Richards, and G.M. Volk. 2012. Identification of interspecific hybrids among domesticated apple and its wild relatives. Tree Genet. Genomes 8:1223-1235.

Guilford, P., S. Prakash, J.M. Zhu, E. Rikkerink, S. Gardiner, H. Bassett, and R. Forster. 1997. Microsatellites in Malus $\times$ domestica (apple): Abundance, polymorphism and cultivar identification. Theor. Appl. Genet. 94:249-254.

Harris, S.A., J.P. Robinson, and B.E. Juniper. 2002. Genetic clues to the origin of the apple. Trends Genet. 18:426-430.

Hokanson, S.C., A.K. Szewc-McFadden, W.F. Lamboy, and J.R. McFerson. 1998. Microsatellite (SSR) markers reveal genetic identities, genetic diversity and relationships in a Malus $\times$ domestica borkh. core subset collection. Theor. Appl. Genet. 97:671-683.

Juniper, B. and D.J. Mabberley. 2006. The story of the apple. Timber Press, Portland, OR.

Korban, S.S. and R.M. Skirvin. 1984. Nomenclature of the cultivated apple. HortScience 19:177180.

Lamboy, W.F., J. Yu, P.L. Forsline, and N.F. Weeden. 1996. Partitioning of allozyme diversity in wild populations of Malus sieversii L. and implications for germplasm collection. J. Amer. Soc. Hort. Sci. 121:982-987.

Liebhard, R., L. Gianfranceschi, B. Koller, C.D. Ryder, R. Tarchini, E. van de Weg, and C. Gessler. 2002. Development and characterization of 140 new microsatellites in apple (Malus $\times$ domestica Borkh.). Mol. Breed. 10:217-241

Luby, J., P. Forsline, H. Aldwinckle, V. Bus, and M. Geibel. 2001. Silk road apples-Collection, evaluation, utilization of Malus sieversii from Central Asia. HortScience 36:225-231. 
Luby, J.J. 2003. Taxonomic classification and brief history, p. 1-14. In: Ferree, D.C. and I.J. Warrington (eds.). Apples: Botany, production and uses. $\mathrm{CAB}$ International, Cambridge, MA.

Luby, J.J., P.A. Alspach, V.G.M. Bus, and N.C. Oraguzie. 2002. Field resistance to fire blight in a diverse apple (Malus sp.) germplasm collection. J. Amer. Soc. Hort. Sci. 127:245-253.

Micheletti, D., M. Troggio, A. Zharkikh, F. Costa, M. Malnoy, R. Velasco, and S. Salvi. 2011. Genetic diversity of the genus Malus and implications for linkage mapping with SNPs. Tree Genet. Genomes 7:857-868.

Phipps, J.B., K.R. Robertson, J.R. Rohrer, and P.G. Smith. 1991. Origins and evolution of subfam. Maloideae (Rosaceae). Syst. Bot. 16:303-332.

Phipps, J.B., K.R. Robertson, P.G. Smith, and J.R. Rohrer. 1990. A checklist of the subfamily Maloideae (Rosaceae). Can. J. Bot. 68:22092269.

Pritchard, J.K., M. Stephens, and P. Donnelly. 2000. Inference of population structure using multilocus genotype data. Genet. 155:945-959.

Richards, C.M., G.M. Volk, P.A. Reeves, A.A. Reilley, A.D. Henk, P.L. Forsline, and H.S. Aldwinckle. 2009a. Selection of stratified core sets representing wild apple (Malus sieversii). J. Amer. Soc. Hort. Sci. 134:228-235.

Richards, C.M., G.M. Volk, A.A. Reilley, A.D. Henk, D. Lockwood, P.A. Reeves, and P.L. Forsline. 2009b. Genetic diversity and population structure in Malus sieversii, a wild progenitor species of domesticated apple. Tree Genet. Genomes 5:339-347.
Robinson, J.P., S.A. Harris, and B.E. Juniper. 2001. Taxonomy of the genus Malus Mill. (Rosaceae) with emphasis on the cultivated apple, Malus domestica Borkh. Plant Syst. Evol. 226:35-58.

USDA, ARS, National Genetic Resources Program. 2013. Germplasm Resources Information Network (GRIN) (online database). National Germplasm Resources Laboratory, Beltsville, MD. 8 June 2013. <http://www.ars-grin.gov/ cgi-bin/npgs/html/crop.pl?115>.

Van Nocker, S., G. Berry, J. Najdowski, R. Michelutti, M. Luffman, P. Forsline, N. Alsmairat, R. Beaudry, M.G. Nair, and M. Ordidge. 2012. Genetic diversity of red-fleshed apples (Malus). Euphytica 185:281-293.

Velasco, R., A. Zharkikh, J. Affourtit, A. Dhingra, A. Cestaro, A. Kalyanaraman, P. Fontana, S.K. Bhatnagar, M. Troggio, D. Pruss, S. Salvi, M. Pindo, S. Castelletti, M. Cavaiuolo, G. Coppola, F. Costa, V. Cova, A. Dal Ri, V. Goremykin, M. Komjanc, S. Longhi, P. Magnago, G. Malacarne, M. Malnoy, D. Micheletti, M. Moretto, M. Perazzolli, A. Si-Ammour, S. Vezzulli, E. Zini, G. Eldredge, L.M. Fitzgerald, N. Gutin, J. Lanchbury, T. Macalma, J.T. Mitchell, J. Reid, B. Wardell, C. Kodira, Z. Chen, B Desany, F. Niazi, M. Palmer, T. Koepke, D. Jiwan, S. Schaeffer, V. Krishnan, C. Wu, V.T. Chu, S.T. King, J. Vick, Q. Tao, A. Mraz, A. Stormo, K. Stormo, R. Bogden, D. Ederle, A. Stella, A. Veccietti, M.M. Kater, S. Masiero, P. Lasserre, E. Lavezzo, J.A. Fawcett, S. Proost, P. Rouze, L. Sterck, S. Toppo, B. Lazzari, R.P. Hellens, C.-E. Durel, A. Gutin, R.E. Bumgarner,
S.E. Gardiner, M. Skolnick, M. Egholm, Y. Van de Peer, F. Salamini, and R. Viola. 2010. The genome of the domesticated apple (Malus $\times$ domestica Borkh.). Nat. Genet. 42:833-839.

Volk, G.M., C.M. Richards, A.A. Reilley, A.D Henk, P.L. Forsline, and H.S. Aldwinckle. 2005. Ex situ conservation of vegetativelypropagated species: Development of a seedbased core collection for Malus sieversii. J. Amer. Soc. Hort. Sci. 130:203-210.

Wan, Y., D. Li, Z. Zhao, L. Mei, M. Han, H. Schwaninger, and G. Fazio. 2011. The distribution of wild apple germplasm in northwest China and its potential for apple rootstock breeding. Acta Hort. 903:123-141.

Yamamoto, T., T. Kimura, M. Shoda, Y. Ban, T. Hayashi, and N. Matsuta. 2002. Development of microsatellite markers in the Japanese pear (Pyrus pyrifolia Nakai). Mol. Ecol. Notes 2:14-16.

Yan, G., H. Long, W. Song, and R. Chen. 2008. Genetic polymorphism of Malus sieversii populations in Xinjiang, China. Genet. Resources Crop Evol. 55:171-181.

Zhou, Z.Q. 1999. The apple genetic resources in China: The wild species and their distributions, informative characteristics and utilisation. Genet. Resources Crop Evol. 46:599-609.

Zhou, Z.Q. and Y.N. Li. 2000. The RAPD evidence for the phylogenetic relationship of the closely related species of cultivated apple. Genet. Resources Crop Evol. 47:353357. 
Malus sieversii. pg. 1
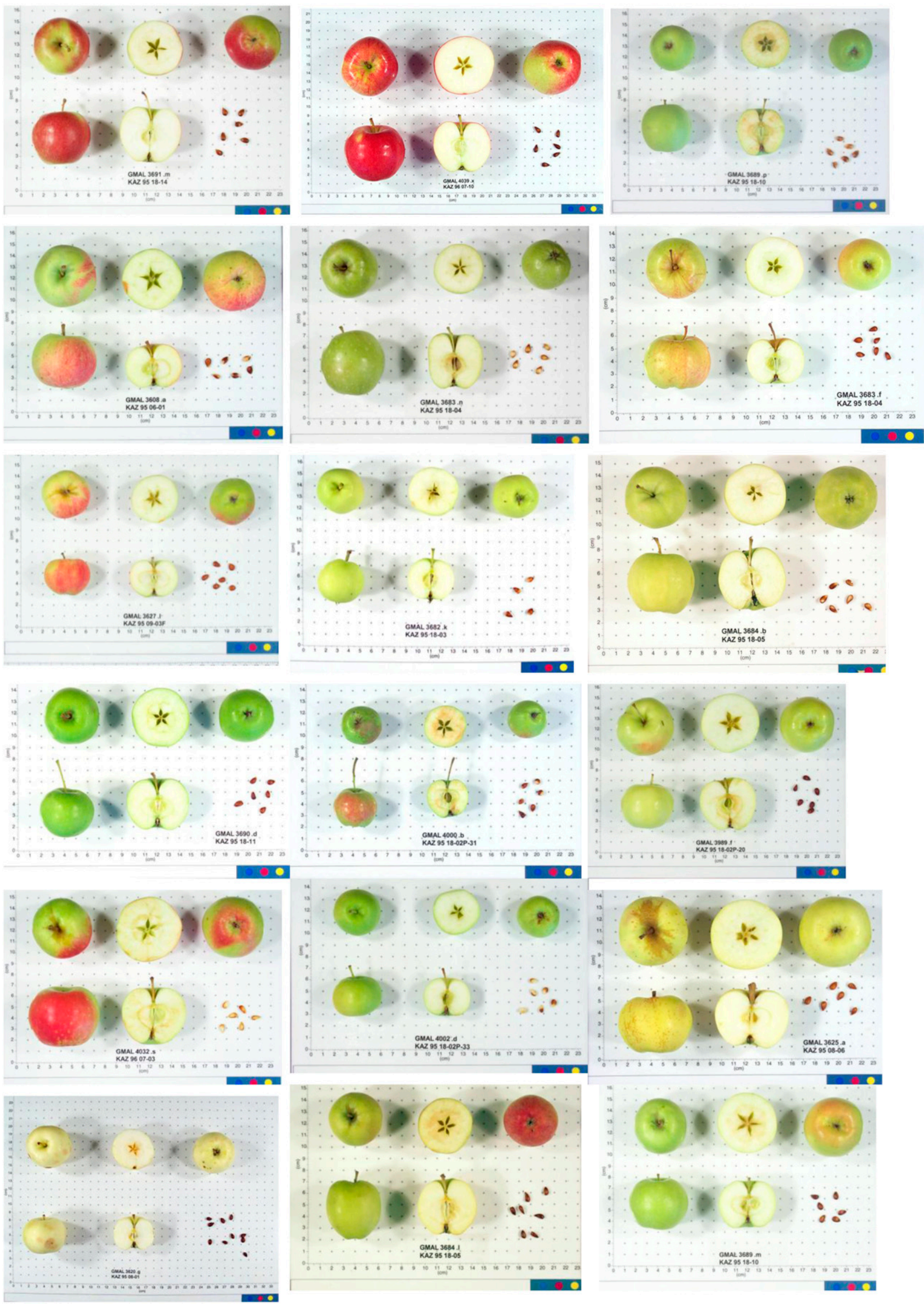

Supplementary Fig. 1. Fruit images from Genetic Resources Information Network for Malus pumila, M. pumila var. niedzwetzkyana, M. sieversii var. kirghisorum, M. sieversii var. turkmenorum, and M. sieversii. 


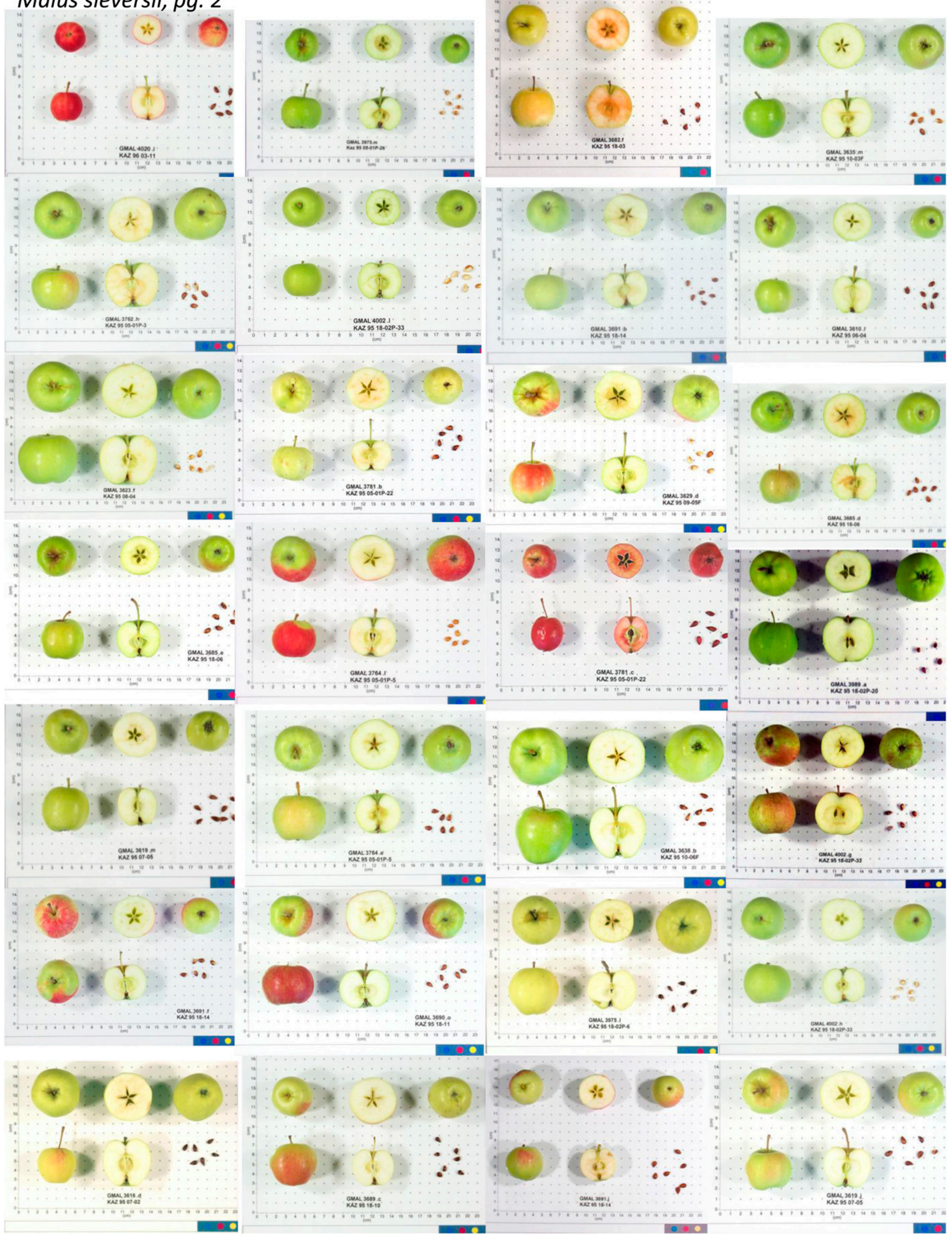


Malus sieversii, pg. 3

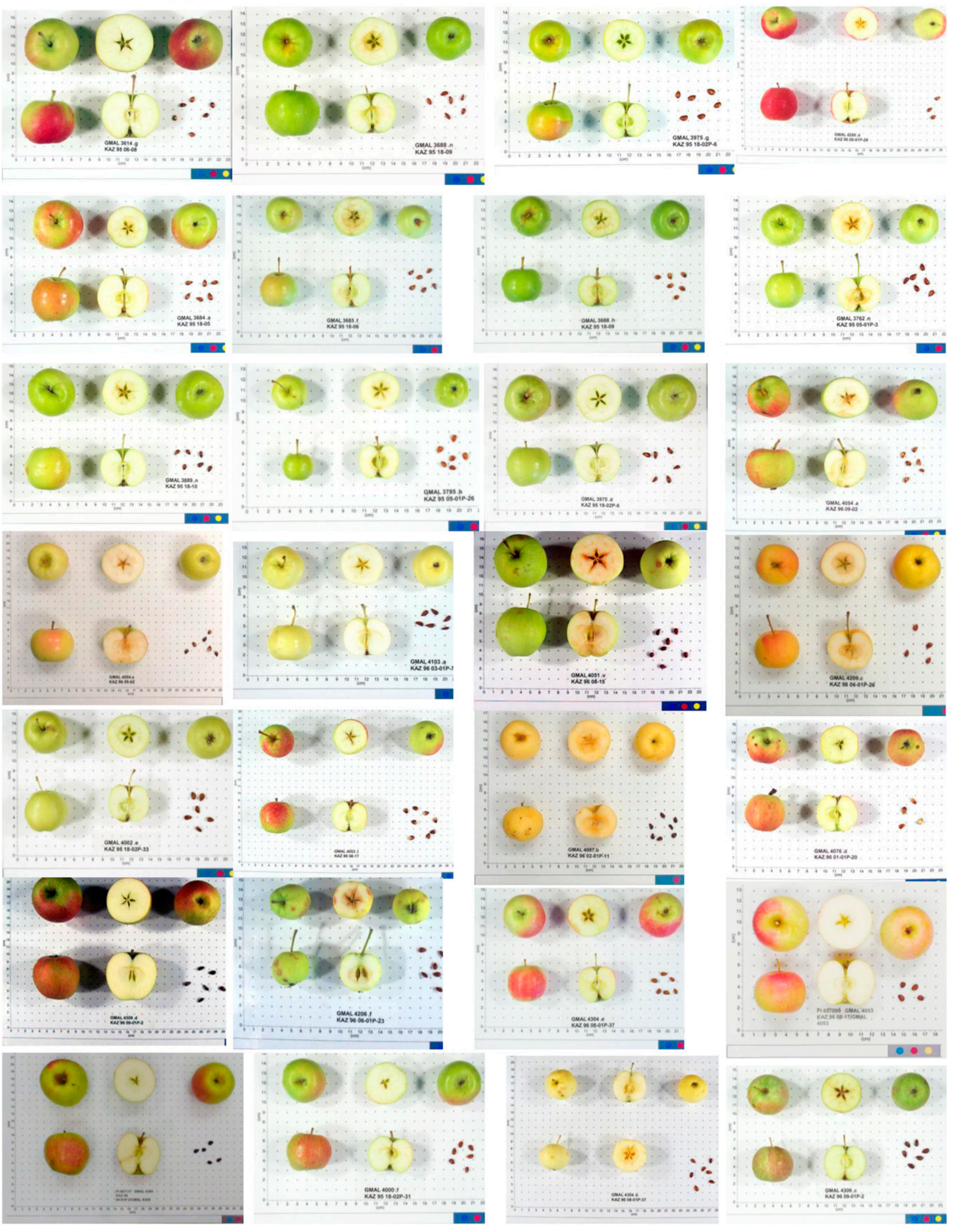

Supplementary Fig. 1. Continued. 


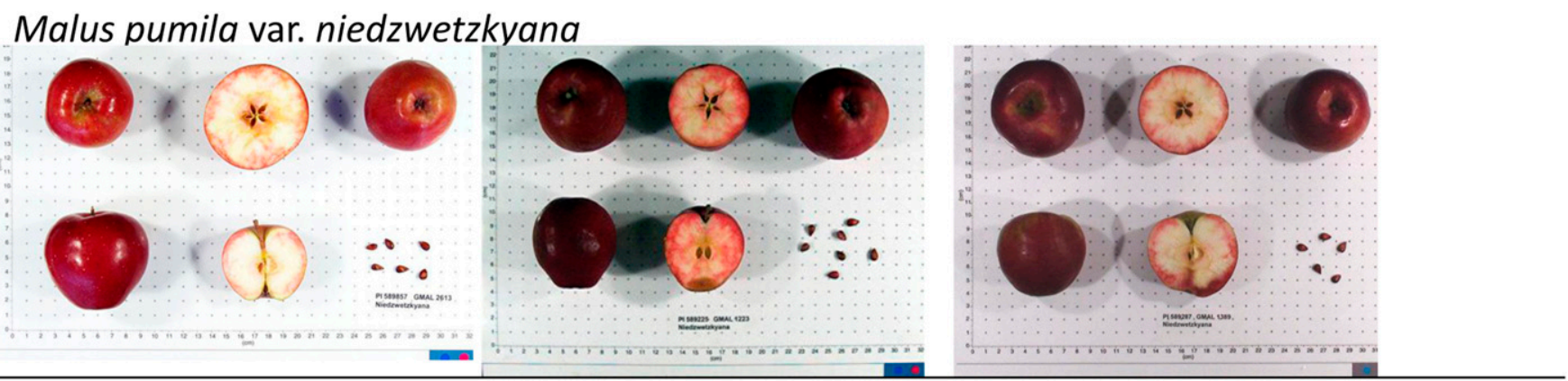

\section{Malus sieversii var. kirghisorum}
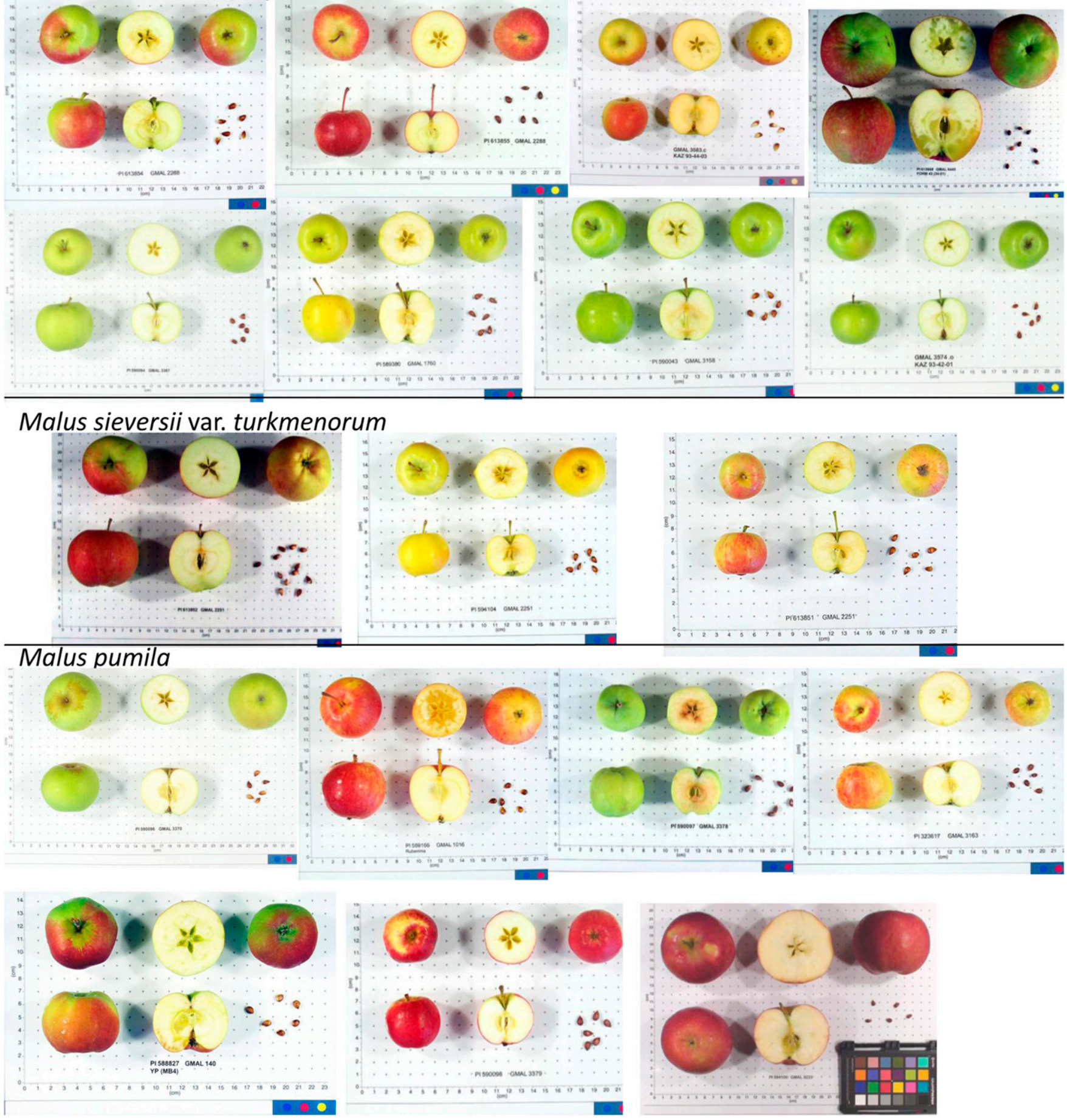

Supplementary Fig. 1. Continued. 